\section{AN UNDEVELOPED ASPECT OF ENGINEERING TRAINING.}

A SURVEY of the careers of students who A enter the engineering profession after a technical training at a university reveals the fact that in very many cases the student, within a comparatively short time of his leaving the university, finds himself in need of knowledge which his training has neither provided nor even suggested would in time be required. This fact was emphasised. in a paper recently presented to the Institution of Electrical Engineers by Lt.-Col. W. A. J. O'Meara, who urged the inclusion in the training of engineers of courses of instruction relating to non-technical subjects, such as bookkeeping, custodianship, administration, law, etc. Further emphasis is given to this point of view by the considerable amount of published matter relating to various aspects of management in connection with industrial affairs, with much of which the engineer is nowadays directly concerned.

In most of the British universities having faculties of engineering, technical studies represent the outstanding feature of instruction, and it must be admitted that such studies will always be the real backbone of an engineer's training. At the same time, with changing industrial conditions, technical instruction alone-presupposing that this will be followed by a period of practical training-is not an adequate preliminary equipment for an engineer. Consider, for instance, a student who enters a manufacturing branch of the engineering industry-a branch which offers the widest scope and attracts probably the greatest numbers of technically trained men. Such a student will, after his works training, find that his natural interests lie in the direction either of the commercial, technical, works administration, or research department of the organisation. In any one of these departments it is of fundamental importance that he should have a thoroughly sound grasp of the principles of industrial economics, since a cardinal feature of all manufacturing effort is to produce economically, and this is not possible if the basis on which costs are computed and compared is not fully understood. An engineer will be a better designer, for instance, if he can discuss intelligently with the works management details of manufacturing cost. Similar ability is of value to the commercial engineer, and will enable him to appraise correctly the strong and weak features of competitors' efforts. Such knowledge is not at present available in most of the courses of instruction for engineers, although many universities and colleges are paying attention to the matter. In some large works this instruction is given to members of the staff, including the technically trained apprentices, who can make best use of the knowledge, but it is important that works costing and accounting should occupy a much more definite position in the regular instruction of the engineer.

In view of the already overcrowded courses, NO. 2594, VOL. IO3] the main principles underlying these studies could be taught to the student before he enters the university, and he might receive instruction in their practical application, either in post-graduate courses in the university, or by systematic instruction in the works into which he ultimately proceeds.

Another most important subject is that broadly covered by the term "industrial administration," comprising modern methods of management. Shortened hours and increased wages, together with the burdens of taxation imposed by war, emphasise the necessity for increased and more efficient production, and bring to the fore the importance of the prevention of waste, whether relating to time, effort, or materials; a study of the periods of working that will result in optimum effort; factory conditions as regards lighting, ventilation, the supply of food, and everything that conserves the health and vitality of the workers; the selection of workers so that the job is adapted to their characteristics rather than that they should be forced to adapt themselves to fixed conditions imposed by the character of their work; and means for improving the collective efficiency of workers and management by ensuring harmonious relations between them. Related to this subject is the all-important one of the education of both the juvenile and the adult worker, the former being particularly pressing in view of the new Education Act.

We should like to see the principles of industrial administration laid down in the university courses in so far as this can be done without jeopardising the value of the present curriculum. In this connection it is interesting to note that at the Municipal College of Technology, Manchester, a directorship in industrial administration has been set up, which not only provides public lectures to which managers and others interested in industry are invited, but' also affords a fulltime course of instruction to young men who desire to prepare themselves for managerial positions in industry.

\section{RECONSTRUCTION PROBLEMS.}

THE Ministry of Reconstruction is issuing a series of pamphlets which deserves to be very widely read by the public, as they bring briefly and yet clearly to notice a number of considerations of great importance, though probably not familiar to everyone. Two of these pamphlets bear the titles "The Classics in British Education" (No. 2I) and "Natural Science in British Education"' (No. 26).

It is remarkable, notwithstanding the discussions which have been going on during the last forty years or more on the conflict between literature and science in education, how much confusion still exists, even in the minds of fairly well informed people, as to the aims of the two parties in the controversy. It is a misfortune that the word "science" has become perverted from its original meaning to such an extent that it now 
seems to connote something mysterious and apart from ordinary modes of thought or practice, whilst, as Huxley pointed out long ago, science is just common knowledge, but exact and purified from error whether in observation or inference. In the words of the pamphlet, science should be "treated as one of the humanities or a record of the progress of human thought applied to the solutions of the problems of Nature."

Sir Joseph Thomson's Committee, the report of which is largely the theme of this publication, states: "We are by no means sure that the popular interest in science is as great to-day as it was thirty years ago." This is a point which might well be regarded as debatable, in view of the constant talk about the marvels of modern scientific discovery and invention, but that ignorance still prevails in unexpected quarters is quite true. It seems necessary that the education of those especially who are likely to become members of the ruling class should be so far rectified that in the next generation it can no longer be said that the Ministry of the Crown is from top to bottom ignorant of the most rudimentary ideas in this direction.

As concerns the subject of the other pamphlet under notice, there is much here that deserves careful thought. We may agree that "the real enemy of education is want of faith in its value," and deplore the general tendency to look for purely utilitarian results. We may agree that " if there is one thing more certain than another it is that the Allies won the war because their moral ideals were higher than those of Germany," while we may demur to the assumption that these arise to any preponderant extent out of the study of the Greek and Latin classics.

The pamphlet is composed in a laudable spirit of liberality towards other studies, and it is well that each side should remember that "one mind responds best to one stimulus and one to another," but it remains clear that a mind nourished on purely literary material, while careless of the physical universe, is not only deprived of one great source of delight, but is also incapable of perceiving many of the influences which are at work in shaping human destinies.

\section{THE RETURN OF $R 34$.}

THE rigid airship $\mathrm{R} 34$ has successfully accomplished the return flight from New York to Pulham, in Norfolk, where it landed safely on July 13 , having left Long Island on July ro. As might have been expected from the direction of the prevailing winds, the return journey was made in considerably less time than the outward crossing, occupying only 75 hours, as against 108 for the previous flight. The highest speed recorded on the return crossing was 72 knots, or nearly 83 miles per hour. One of the engines broke down completely in mid-Atlantic, but this did not seriously hamper the airship, the full power of which was only used when severe head-winds were encountered. Major Scott's account of the voyage seems to indicate that thick fogs are the airship's worst enemy, preventing, as they do, the observations which are required to determine the course. A dead reckoning by compass and air-speed indicator is still possible in a fog, but this only gives the course relatively to the air, and takes no account of the motion of the air relatively to the earth.

The start homeward was hurriedly arranged to prevent the airship being caught in a gale at her moorings, and the strong westerly wind which was blowing at the time enabled $\mathrm{R}_{34}$. to make rapid headway on her course eastwards. Weather conditions on the homeward passage were very similar to those prevailing over the Atlantic during the outward voyage, but the more southerly route followed on the western side of the ocean led to the avoidance of much bad weather. Anticyclonic conditions have prevailed over the open Atlantic for some time past, but a change may reasonably be expected soon. After the summer weather conditions have broken up, Atlantic flight by any class of machine will probably be in abeyance for several months. The Times of July $\mathbf{5}_{5}$ says:-

Some remarkable wireless signals were exchanged during the voyage of the $R_{34}$. The Royal Air Force station at Dundee exchanged signals at rooo miles. The $R_{34}$ sent messages at I Ioo miles that were read by the Air Ministry and by Wormwood Scrubs at I 35 miles, and by Ballybunion at 1600 miles. In one case, when the $\mathrm{R}_{34}$ was approaching America, a signal was sent to her from the Air Ministry through Clifden, and a reply received via St. John's, Glace Bay, Clifden, and Marconi House, and then to the Air Ministry, all in twenty minutes-a very fine example of wireless telegraphy work.

The double crossing of the $\mathrm{R}_{34}$ must be regarded as a very great achievement in the history of aeronautics, a flight of 7600 miles in two stages being an enormous advance on previous records. The airship has also abundantly proved its capability to withstand fairly severe weather without mishap. The possibility of commercial trans-Atlantic airships seems to be mainly governed by the question of speed. The cost of transport is at present very much higher for aircraft than for even the most rapid means of land and sea communication, and it is only in virtue of high speed that aircraft will find their use in the commercial world-at any rate for the next few years. The question is further complicated by the fact that airships may meet adverse winds having velocities equal to, or even greater than, their own maximum speed, whereas the ocean liner has only to contend against currents of very low velocity compared with its own steaming speed. The airship, like the steamship, is most economical to run at low speeds, and analogy would lead one to expect that only by greatly increasing the size of airships can high speed and commercial success be attained, exactly as has been the case with the ocean liner. Whatever the future may hold in store, we cannot fail to admire the wonderful achievement of the $R_{34}$, 